\title{
Risk factors associated with selected indicators of milk quality in semiarid northeastern Brazil
}

\author{
C. J. B. Oliveira, ${ }^{\star 1}$ W. D. Lopes Júnior, ${ }^{\star}$ R. C. R. E. Queiroga,† P. E. N. Givisiez, ${ }^{\star}$ P. S. Azevedo, ${ }^{\star}$ W. E. Pereira, $\ddagger$ \\ and W. A. Gebreyes§ \\ *Department of Animal Science, Federal University of Paraiba, Areia-PB, 58397-000, Brazil \\ †Department of Nutrition, Federal University of Paraiba, João Pessoa-PB, 58059-900, Brazil \\ ‡Department of Social and Fundamental Sciences, Federal University of Paraiba, Areia-PB, 58397-000, Brazil \\ $\S$ Department of Veterinary Preventive Medicine, College of Veterinary Medicine, The Ohio State University, Columbus 43210
}

\begin{abstract}
The aim of this study was to gain information on quality traits, mainly bacterial and somatic cell counts of bulk milk, produced by small- and medium-scale producers in a semiarid northeastern region of Brazil and to identify and characterize possible risk factors associated with those quality traits. A cross-sectional study was performed on 50 farms. Bulk milk samples were collected for bacterial and somatic cell counts. Additionally, information about farm demographics, general management practices, hygiene, and milking procedures was also obtained. Multivariable analysis using logistic regression was performed with predictors previously identified by univariate analysis using a Fisher's Exact test. Aerobic mesophilic bacteria counts varied from $3.59 \log$ to $6.95 \log \mathrm{cfu} / \mathrm{mL}$, with geometric mean of $5.27 \log \mathrm{cfu} / \mathrm{mL}$. Mean total coliform count was $3.27 \log (1.52 \log$ to $5.89 \log$ ) most probable number $(\mathrm{MPN}) / \mathrm{mL}$, whereas mean thermotolerant coliforms was $2.38 \log (1.48 \log$ to $4.75 \log ) \mathrm{MPN} / \mathrm{mL}$. A high positive correlation was observed between aerobic mesophilic bacteria and coliform counts. Although most farms met the standard for the current regulations for total bacteria (88\%) and somatic cell counts (94\%), nearly half of the producers (46\%) would have problems in achieving the 2012 threshold limit for total bacteria count if no improvement in milk quality occurs. Mean value for staphylococci was $3.99 \log$ (2.31 log to 6.24 $\log ) \mathrm{cfu} / \mathrm{mL}$, and Staphylococcus aureus was detected in $33(66 \%)$ farms. Premilking teat-end wash procedure (odds ratio $=0.191$ ) and postmilking teat dip (odds ratio $=0.67$ ) were associated with lower aerobic mesophilic bacteria and Staphylococcus aureus counts in bulk milk, respectively. Considering that the farm characteristics in this study are representative of the semiarid northeastern region, these findings encourage
\end{abstract}

Received May 25, 2010.

Accepted February 13, 2011.

${ }^{1}$ Corresponding author: celso.oliveira@pq.cnpq.br further investigations for supporting intervention measures intended to improve the quality of milk produced by smallholders.

Key words: bacterial count, dairy, smallholder milk producer, somatic cell count

\section{INTRODUCTION}

Milk contamination by pathogenic microorganisms is considered a major public health issue worldwide (Nero et al., 2003; Jayarao et al., 2006), especially in developing regions, where raw milk is frequently consumed by the population, including children and the elderly. Marketing of raw milk is illegal in Brazil, but cultural habits and lack of information on public health issues make its consumption a common practice among individuals of low social status.

In addition, the physicochemical and sensory attributes of milk and dairy products are largely affected by microbiological contamination of raw milk (Barbano et al., 2006). Thermo-resistant enzymes and toxins produced by some bacterial species can negatively affect sensory attributes and safety of pasteurized milk and dairy products. Therefore, improvement and monitoring of raw milk quality is a major issue for the development of the milk production chain worldwide.

The Brazilian Ministry of Agriculture (MAPA) has launched a national program for the improvement of milk quality ("Programa Nacional de Melhoria da Qualidade do Leite - PNMQL") and substantial changes in the federal legislation regarding milk have been implemented (Brasil, 2002). This program has established lower tolerance limits for bacterial and SCC in raw milk in the 5 regions of the country. For the northeast region, the limit initially established (until July 2010) for mesophilic aerobic bacteria (cfu/mL) and SCC (cells/mL) was 1,000,000. From July 2010 until July 2012, the maximum threshold was decreased to 750,000 for both parameters. From July 2012 onward, the tolerance limits for mesophilic aerobic bacteria and SCC will be $300,000 \mathrm{cfu} / \mathrm{mL}$ and 400,000 cells $/ \mathrm{mL}$, re- 
spectively. Currently, information on the baseline data of these values in milk produced in the northeastern Brazil region is lacking.

Milk production in the northeast region increased by $54 \%$ between 1998 and 2006 (IBGE, 2008) and is considered one of the most important economic drivers in this part of the country. The dairy industry in this region normally comprises small- and medium-scale family cattle producers using crosses of Zebu (Bos indicus) and Holstein (Bos taurus) managed extensively or semi-intensively. Although improvements have been observed in recent years, milk productivity is still very low. Budget limitations and lack of technical knowledge are key factors that could jeopardize attainment of the minimal quality requirements established in the current legislation. Knowledge about factors associated with milk quality traits in such production systems could support intervention measures to improve the quality of milk produced in developing regions. Indeed, most scientific information on the factors affecting milk quality available in the literature relates to studies performed in intensive systems using specialized animals and automated milking systems (Barkema et al., 1999; Peeler et al., 2000; Suriyasathaporn et al., 2000; Elmoslemany et al., 2009a).

Because of the lack of comprehensive data needed to establish baseline values on milk quality produced in the region, our aim in this study was to assess microbiological traits and SCC in raw milk yielded in extensive production systems from a semiarid region and to tentatively identify risk factors associated with those traits toward the implementation of control measures intending to improve milk quality.

\section{MATERIALS AND METHODS}

\section{Study Design and Milk Sampling}

Fifty dairy farms were randomly selected by drawing among members of a dairy cooperative located in Caturité and Boqueirão municipalities in Cariri, a semiarid region of Paraiba State. Both municipalities are major milk suppliers for the cooperative (83 members in Caturité and 91 members in Boqueirão), and all producers (members and nonmembers) supply approximately one-third of the total milk production of the region $(15,789,000 \mathrm{~L} / \mathrm{yr})$. The milk chain in Paraiba State comprises mainly smallholder producers and is characterized by low production $(1,097.92 \mathrm{~L} /$ cow per year on average, with 208,324 cows producing 228,724,000 L/ yr; IBGE, 2008); therefore, only small-scale $(<50 \mathrm{~L} / \mathrm{d})$ and medium-scale $(50-500 \mathrm{~L} / \mathrm{d})$ farms were sampled. The sampling size was restricted to 50 farms because of budget limitations. This sample size allowed detection of odds ratios (OR) of $\geq 9.0$ at the $95 \%$ level of confidence, given a power of $80 \%$ and percentage of farms with high bacterial/SCC group unexposed to a given risk factor of $10 \%$. Samplings were performed during dry and wet seasons from April to September 2008. Duplicate milk samples $(500 \mathrm{~mL})$ were collected from refrigerated bulk tanks on farms that had their own individual tanks. Most smallholder producers in the region share collective storage tanks for cooling milk. In such cases, duplicate samples were directly collected from milk buckets from each individual farm just before milk was placed into the collective bulk tank. Sampling procedures followed National Mastitis Council recommendations (NMC, 1999) using previously sterilized material. Samples were kept under refrigeration until analyses, which were performed within $6 \mathrm{~h}$ of sampling.

\section{Data Collection}

On-farm data on possible risk factors were collected by a questionnaire containing 44 closed-ended and fillin-the-blank questions organized in 3 sections: (1) farm demographics and characterization; (2) general management practices; and (3) hygiene and milking procedures. A prototype of the questionnaire (Supplementary file; available online at http://www.journalofdairyscience. org/) was initially tested on 5 farms located in the survey area and was modified appropriately considering the characteristics of the semi-extensive dairy herds in the region and limitations in the farmer's educational level and communication skills. The questionnaires were completed on the farms during the milking procedure. Whenever possible, the collected information was checked visually. To reduce variations intrinsic to subjective evaluations, such as herd's hygiene status, the questionnaire was applied by the same investigator throughout the survey

\section{Bacteriological Analysis}

Mesophilic aerobic bacteria counts were performed after milk was serially diluted (1:10) in quarter-strength Ringer's solution and plated in plate count agar (Oxoid, Basingstoke, UK), according to protocol described by $\mathrm{AOAC}(1998)$. Petri dishes were incubated at $35^{\circ} \mathrm{C}$ for $48 \pm 2 \mathrm{~h}$.

Total and thermotolerant coliform counts $\left(30 / 35^{\circ} \mathrm{C}\right.$ and $45^{\circ} \mathrm{C}$, respectively) were obtained using the most probable number (MPN) technique according to AOAC (1998). Milk aliquots $(1 \mathrm{~mL})$ from each dilution were transferred to a 3 -tube series of lauryl sulfate triptose broth (Acumedia, Lansing, MI) with inverted Durham tubes. After incubation at $35^{\circ} \mathrm{C}$ for $48 \mathrm{~h}$, the MPN of total coliforms per milliliter of milk was confirmed by 
transferring aliquots $(10 \mu \mathrm{L})$ of positive lauryl sulfate triptose tubes to brilliant green bile broth (Acumedia), which was incubated at $35^{\circ} \mathrm{C}$ for $48 \mathrm{~h}$. Thermotolerant coliforms $\left(45^{\circ} \mathrm{C}\right)$ were determined using Escherichia coli broth (Acumedia) incubated at $44.5 \pm 0.1^{\circ} \mathrm{C}$ for 24 to $48 \mathrm{~h}$ in a water bath.

Staphylococci were enumerated in milk according to APHA (1992) with minor modifications. Samples $(25 \mathrm{~mL})$ were initially diluted in $225 \mathrm{~mL}$ of lactose broth (Acumedia) and then serially diluted (1:10) in quarter-strength Ringer's solution. Aliquots $(100 \mu \mathrm{L})$ were transferred to Petri dishes in duplicates and Baird-Parker agar (Acumedia) supplemented with potassium tellurite and egg yolk (Laborclin, Pinhais-PR, Brazil) was added by the pour-plate method. Plates were incubated at $35^{\circ} \mathrm{C}$ for 24 to $48 \mathrm{~h}$. Colonies showing morphological characteristics were Gram-stained and evaluated for catalase. Presumptive Staphylococcus aureus colonies were tested for coagulase in tubes using rabbit plasma and for acetoin production by VogesProskauer test.

Qualitative detection of Salmonella enterica was performed according to Andrews and Hammack (2007) with minor modifications. Briefly, milk samples (25 g) were pre-enriched in lactose broth (Acumedia) at 1:9 (wt:vol) ratio for $18 \mathrm{~h}$, and then aliquots of $0.1 \mathrm{~mL}$ and $1 \mathrm{~mL}$ were transferred to Rappaport-Vassiliadis broth and tetrathionate broth (Acumedia), respectively. The Rappaport-Vassiliadis tubes were enriched at $42^{\circ} \mathrm{C}$ for $48 \mathrm{~h}$ and the tetrathionate broth at $35^{\circ} \mathrm{C}$ for $24 \mathrm{~h}$. Aliquots were streaked onto xylose lysine desoxycholate agar (Acumedia) and Hektoen enteric agar (Acumedia) plates, which were incubated at $35^{\circ} \mathrm{C}$ for $24 \mathrm{~h}$. Presumptive black colonies were inoculated in triple sugar iron (Acumedia) and lysine iron slants (Acumedia). Salmonella was confirmed by slide agglutination test using polysomatic antisera (Probac, Sao Paulo-SP, Brazil).

\section{SCC}

Somatic cell count was determined using direct microscopy as suggested by Prescott and Breed (1910), according to recommendations from FDA (2005), with minor modifications. Duplicate circular smears $\left(1 \mathrm{~cm}^{2}\right)$ were produced on glass slides using $10-\mu \mathrm{L}$ aliquots. After drying, smears were fixed in methanol for 15 min and then stained with Rosenfeld solution (methylene blue, eosin, and methanol) for $4 \mathrm{~min}$. Afterward, Rosenfeld dye was washed and slides were immersed in a solution containing Rosenfeld and distilled water 1:2 (vol:vol). Smears were then washed with water and dried at room temperature. Counts were performed in 60 microscopic fields using optical microscopy (E-200, Nikon, Tokyo, Japan) at 1,000× magnification (immer- sion objective). Somatic cell numbers were calculated by multiplying the average number of cells in the 60 fields by the microscopic factor $(3,183.09)$ and by the dilution factor (100) for $1 \mathrm{~mL}$ of milk.

\section{Data Analyses}

Logarithmically transformed data of bacterial counts and SCC were used for statistical analysis. Descriptive statistics using transformed data were used to determine geometric means, minimum, and maximum values. Coefficients of correlation were calculated between microbiological and somatic cell determinants. To test the main hypothesis; that is, the presence of on-farm risk factors significantly associated with milk quality indicators, the thresholds used for categorizing the dairy herds regarding high or low aerobic mesophilic bacteria and high or low SCC in raw milk were 5.48 $\log \left(3 \times 10^{5}\right) \mathrm{cfu} / \mathrm{mL}$ and $5.6 \log \left(4 \times 10^{5}\right)$ cells $/ \mathrm{mL}$, respectively. These threshold values were selected based on the regulation limits for both indicators in Brazilian dairy herds to be implemented in 2012. Considering the absences of legislation limits for coliform and staphylococci counts in bulk tank milk, the 75th percentile of observed data was used as threshold.

Univariate analysis by the Fisher Exact test was performed to screen potential risk factors associated with bacterial and somatic cell counts. Only significant unconditional associations $(P<0.2)$ were selected for inclusion in the subsequent multivariable analyses using logistic regression. Predictors were entered stepwise into the logistic regression models by forward selection for aerobic mesophilic bacteria and somatic cell counts. Only variables that were significant at $P<0.05$ by likelihood ratio were considered in the final models. Odds ratio were estimated with respective confidence intervals at $95 \%$. Tetrachoric correlation among all predictors was determined to examine possible collinearity problems.

\section{RESULTS}

\section{Farm Information}

The on-farm data for farm demographics and characterization, general management practices, and hygiene and milking procedures are shown in Tables 1, 2, and 3 , respectively. The majority of the farms $(76 \%)$ were semi-intensive and in most of them (66\%) milking was performed by a single milker only. The dairy farms had low milk production ( $68 \%$ of the farms yielded $<10 \mathrm{~L} /$ animal daily), and $62 \%$ of the farms had 10 or fewer milking cows. On most farms (86\%), the cows were milked manually. Milking room was observed in 20 
Table 1. Unconditional associations $(P<0.2)$ between farm demographics and general characteristics of 50 dairy herds in semiarid northeastern Brazil and on-farm predictors for bulk milk quality indicators

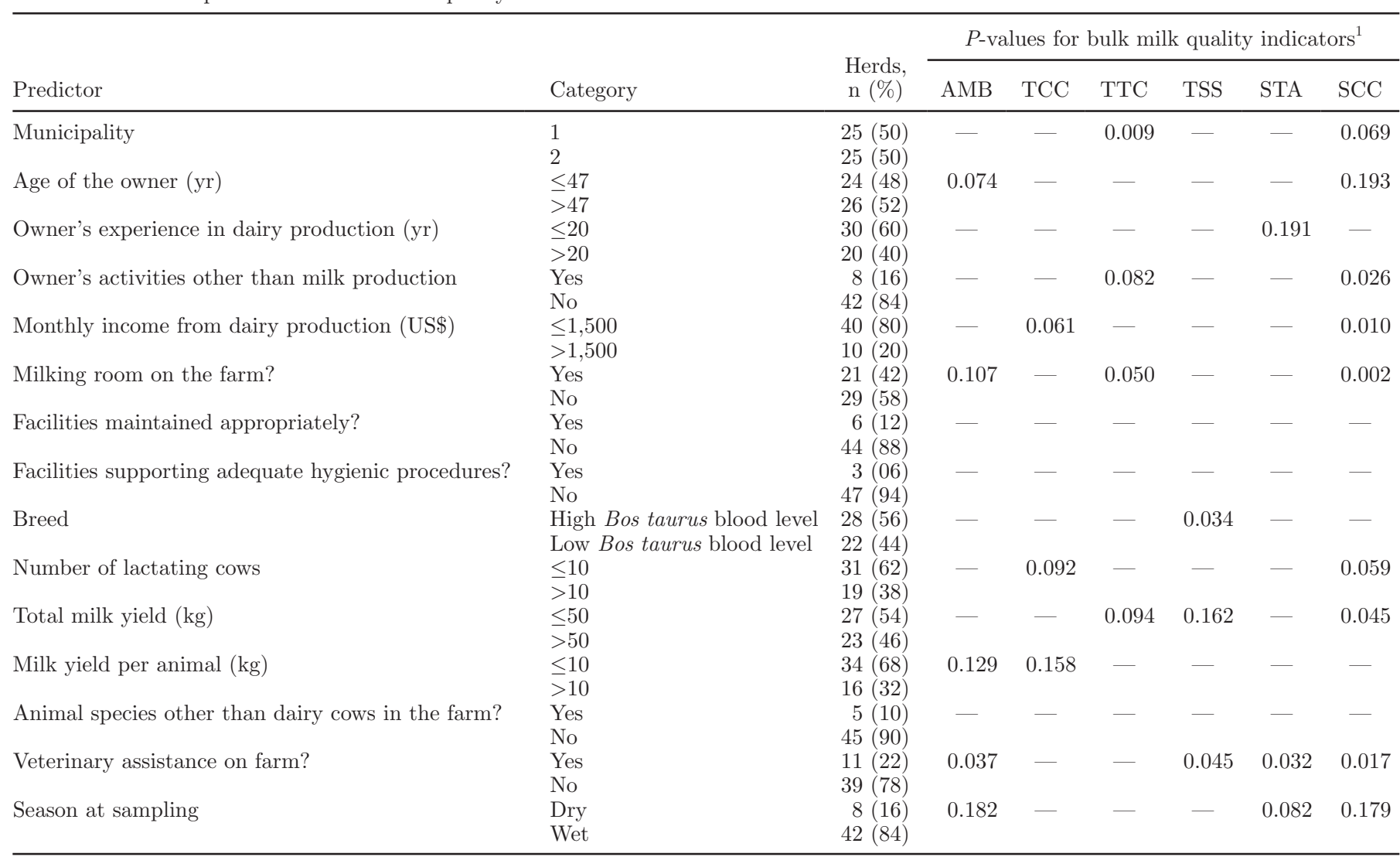

${ }^{1}$ Indicators: $\mathrm{AMB}=$ aerobic mesophilic bacteria; TCC $=$ total coliform count; TTC $=$ thermotolerant coliform; TSS = total staphylococci, STA $=$ Staphylococcus aureus count.

(40\%) of the farms, whereas milking was usually performed in the holding pens in most of the farms (60\%). Veterinary assistance was used in only $11(22 \%)$ of the farms. These characteristics are typically related to the production systems in semiarid northeastern Brazil and allow information to be inferred to similar regions in other states in northeastern Brazil.

\section{Microbiological Findings}

Plate counts for mesophilic aerobic bacteria varied from $3.59 \log \left(3 \times 10^{5}\right)$ to $6.95 \log \left(8.8 \times 10^{6}\right) \mathrm{cfu} / \mathrm{mL}$, with geometric mean of $5.27\left(2.1 \times 10^{5}\right) \mathrm{cfu} / \mathrm{mL}$. The upper thresholds for aerobic mesophilic bacteria established by the Brazilian Ministry of Agriculture (Brasil, 2002) until and after 2012 are $7.5 \times 10^{5}$ and $3.0 \times 10^{5}$ $\mathrm{SCC} / \mathrm{mL}$, respectively.

The mean total coliform count $\left(35^{\circ} \mathrm{C}\right)$ was $3.27 \mathrm{log}$ $\left(2.6 \times 10^{3}\right) \mathrm{MPN} / \mathrm{mL}$ and ranged from 1.52 (33) to $5.89\left(7.8 \times 10^{5}\right) \mathrm{MPN} / \mathrm{mL}$, whereas the mean thermotolerant coliform count $\left(44.5^{\circ} \mathrm{C}\right)$ was $2.38\left(3.8 \times 10^{2}\right)$ $\mathrm{MPN} / \mathrm{mL}$, ranging from $1.48(30)$ to $4.75\left(5.6 \times 10^{4}\right)$ $\mathrm{MPN} / \mathrm{mL}$. A positive correlation was observed between mesophilic aerobic bacteria and coliform counts $(\mathrm{r}=$ 0.78 ) and between mesophilic aerobic bacteria and fecal coliforms $(\mathrm{r}=0.85)$.

The mean value for staphylococci was $3.99(1.3 \times$ $\left.10^{4}\right) \mathrm{cfu} / \mathrm{mL}$, ranging from $2.31\left(2.1 \times 10^{2}\right)$ to $6.24(1.7$ $\left.\times 10^{6}\right) \mathrm{cfu} / \mathrm{mL}$. However, no correlation $(\mathrm{r}=-0.11)$ was observed between staphylococci counts and SCC. Staphylococcus aureus was detected in $33(66 \%)$ farms. In those farms, a mean value of $3.7 \log \left(7.1 \times 10^{3}\right) \mathrm{cfu} /$ $\mathrm{mL}$ was detected and the maximal count was $5.3 \mathrm{log}$ $\left(2.1 \times 10^{5}\right) \mathrm{cfu} / \mathrm{mL}$. Salmonella enterica was detected in only one sample at a prevalence of $2 \%$.

\section{SCC}

Somatic cells ranged from $4.63 \log \left(4.3 \times 10^{4}\right)$ to $6.18 \log \left(1.5 \times 10^{6}\right)$ cells $/ \mathrm{mL}$ with a mean value of $5.38 \log \left(2.4 \times 10^{5}\right)$ cells $/ \mathrm{mL}$. Forty-seven $(94 \%)$ farms presented bulk milk SCC below the maximal threshold $\left(7.5 \times 10^{5}\right.$ cells $\left./ \mathrm{mL}\right)$ of the current Brazilian regulation (Brasil, 2002). If the 2012 scenario is hypothetically considered (i.e., when the threshold will decrease to $4.0 \times 10^{5}$ cells $\left./ \mathrm{mL}\right), 9(18 \%)$ of the farms would not 
Table 2. Unconditional associations $(P<0.2)$ between general management practices of 50 dairy herds in semiarid northeastern Brazil and on-farm predictors for bulk milk quality indicators

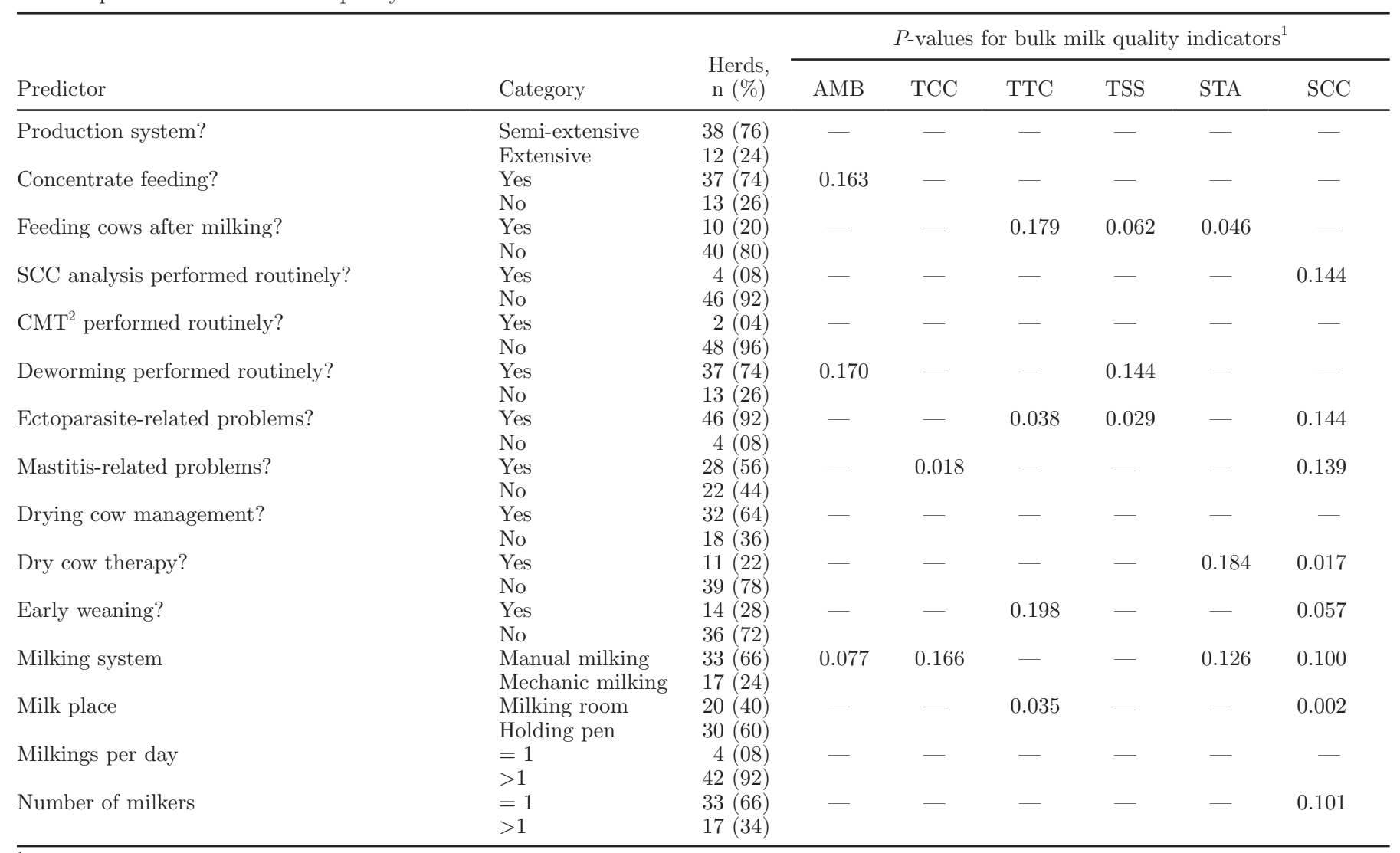

${ }^{1}$ Indicators: $\mathrm{AMB}=$ aerobic mesophilic bacteria; TCC $=$ total coliform count; TTC $=$ thermotolerant coliforms; TSS $=$ total staphylococci, $\mathrm{STA}=$ Staphylococcus aureus count.

${ }^{2} \mathrm{CMT}=$ California Mastitis Test.

meet the legislative threshold breakpoint for acceptable quality.

\section{Risk Factor Analyses}

Univariate analyses performed to screen candidate predictors associated with milk traits indicated unconditional associations (Tables 1, 2, and 3). Demographic predictors linked to bacterial counts were producer's age $(P=0.07)$, presence of milking room on farm $(P=$ $0.11)$, milk yield per animal $(P=0.13)$, and veterinary assistance $(P=0.04)$. Unconditional associations for total coliforms included owner's income $(P=0.061)$, number of lactating cows $(P=0.092)$, and milk yield per animal $(P=0.158)$. For thermotolerant coliforms, municipality $(P=0.021)$, owner's activities other than milk production $(P=0.082)$, milking room on farm $(P$ $=0.050)$, and total milk yield $(P=0.094)$ were selected. Unconditional associations with total staphylococci counts included breed $(P=0.034)$, total milk yield ( $P$ $=0.162)$, and veterinary assistance $(P=0.045)$. For
Staph. aureus, selected predictors were season $(P=$ $0.173)$, owner's experience (0.191), and veterinary assistance $(P=0.032)$. Regarding associations with SCC, the predictors were municipality $(P=0.07)$, producer's age $(P=0.19)$, owner's activities other than milk production $(P=0.026)$, income from dairy production $(P$ $=0.010)$, milking room on the farm $(P=0.00)$, number of lactating cows $(P=0.06)$, total milk yield $(P=$ $0.05)$, and veterinary assistance $(P=0.02)$.

Considering general management practices, use of concentrate $(P=0.016)$, deworming $(P=0.17)$, and milking system $(P=0.08)$ were statistically associated with aerobic mesophilic bacteria. Predictors for total coliforms were mastitis-related problems reported by the farmer $(P=0.018)$ and milking system $(P=0.166)$. For thermotolerant coliforms, feeding cows after milking $(P=0.179)$, ectoparasite-related problems $(P=$ $0.038)$, early weaning $(P=0.198)$, and milking place $(P$ $=0.035)$ were selected for further analysis. Predictors associated with total staphylococci counts were feeding cows after milking $(P=0.062)$, deworming $(P=$ 
Table 3. Unconditional associations between hygiene and milking procedures of 50 dairy herds in semiarid northeastern Brazil and on-farm predictors for raw milk quality indicators

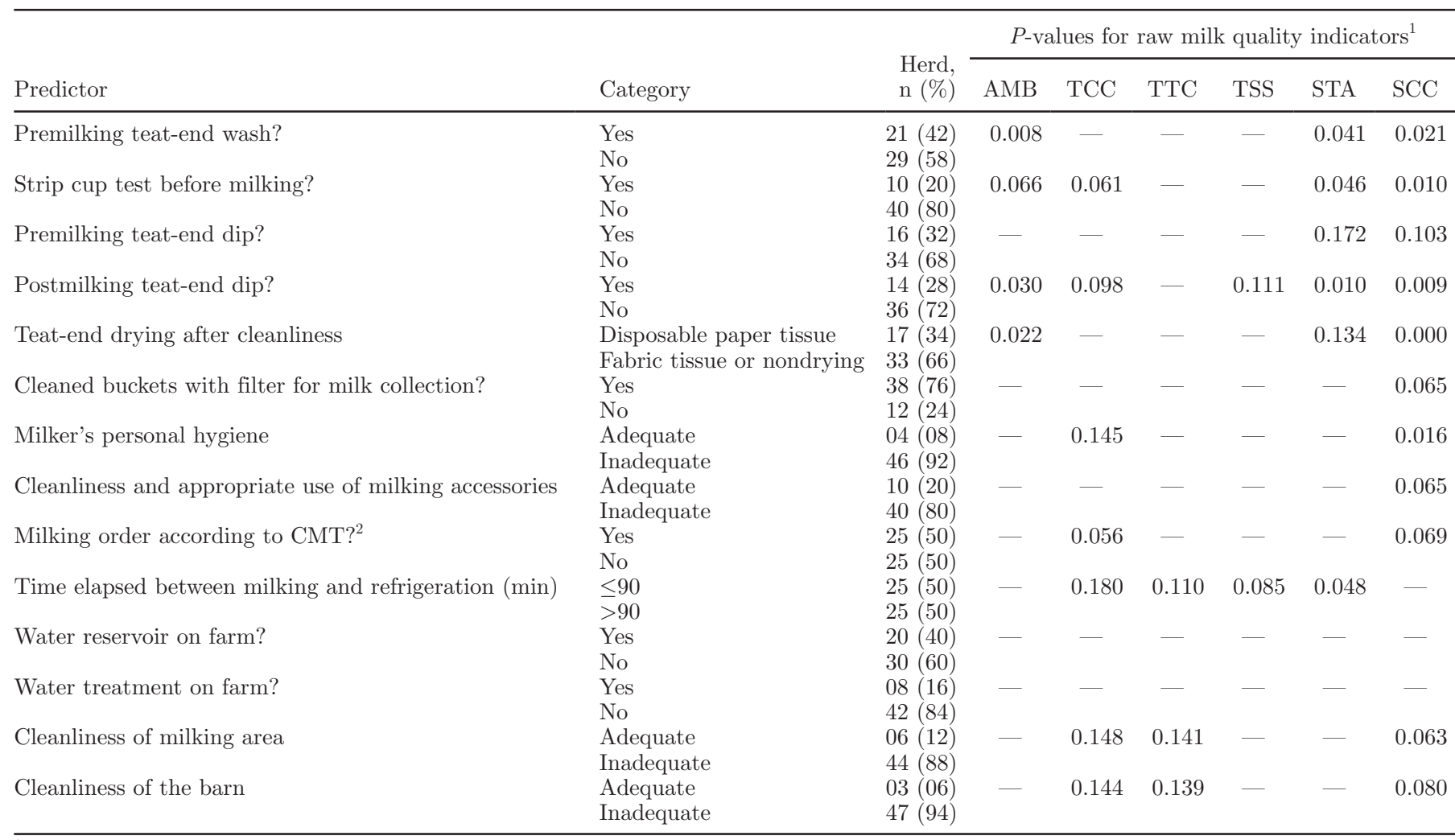

${ }^{1}$ Indicators: $\mathrm{AMB}=$ aerobic mesophilic bacteria; $\mathrm{TCC}=$ total coliform count; $\mathrm{TTC}=$ thermotolerant coliforms; TSS $=$ total staphylococci, $\mathrm{STA}=$ Staphylococcus aureus count.

${ }^{2} \mathrm{CMT}=$ California Mastitis Test.

$0.144)$, and ectoparasite-related problems $(P=0.029)$. Screened variables for Staphylococcus aureus counts included feeding animals after milking $(P=0.046)$, milking system $(P=0.126)$, and medicated drying $(P$ $=0.184)$. For somatic cells, the selected variables were routine cell counts $(P=0.14)$, ectoparasite-related problems $(P=0.14)$, mastitis-related problems $(P=$ $0.14)$, medicated drying of cows $(P=0.02)$, early weaning $(P=0.06)$, milk system $(P=0.10)$, milking place $(P=0.00)$, and number of milkers $(P=0.10)$.

Regarding hygiene and milking procedures, teatwash $(P=0.001)$, strip-cup test $(P=0.07)$, post-dip $(P=0.03)$, and teat-end dry after cleanliness $(P=$ 0.022 ) were selected as predictors for aerobic mesophilic bacteria. For total coliforms, significant variables were strip-cup test $(P=0.061)$, cleanliness of milking area $(P=0.148)$, post-dip $(P=0.098)$, cleanliness of barn $(P=0.144)$, milker's personal hygiene $(P=0.145)$, milking order $(P=0.056)$, and time elapsed until milk refrigeration $(P=0.180)$. For thermotolerant coliforms, cleanliness of the milking area $(P=0.141)$, cleanliness of the barn $(P=0.139)$, and time elapsed between milking and refrigeration $(P=0.110)$ were selected. Predictors associated with total staphylococci were post-dip (0.111) and time elapsed between milking and refrigeration $(P=0.085)$. Teat-end wash $(0.041)$, stripcup test $(P=0.046)$, pre-dip $(P=0.172)$, post-dip $(P$ $=0.010)$, teat-end drying after wash $(P=0.134)$, and time elapsed between milking and milk refrigeration $(P$ $=0.048$ ) were screened predictors for Staphylococcus aureus. For somatic cells, only 3 variables were not selected $(P>0.2)$ : time elapsed between milking and milk refrigeration, on-farm water treatment, and onfarm water reservoir.

Table 4 presents the risk factors $(P<0.05)$ associated with bacterial counts and SCC determined by the multivariable analyses. According to the final logistic regression models, teat-end wash procedure was the only predictor $(P<0.05)$ associated with reduction of aerobic mesophilic bacteria in raw milk produced by smallholders in the semiarid region. Increased total coliform counts in raw milk were associated with mastitis-related problems reported by the farmer, whereas thermotolerant coliform count variations in raw milk 
Table 4. Final logistic regression model for on-farm predictors associated with aerobic mesophilic bacteria, total coliform, thermotolerant coliform, total staphylococci, Staphylococcus aureus, and SCC in bulk tank milk in the semiarid region of Paraiba State, Brazil

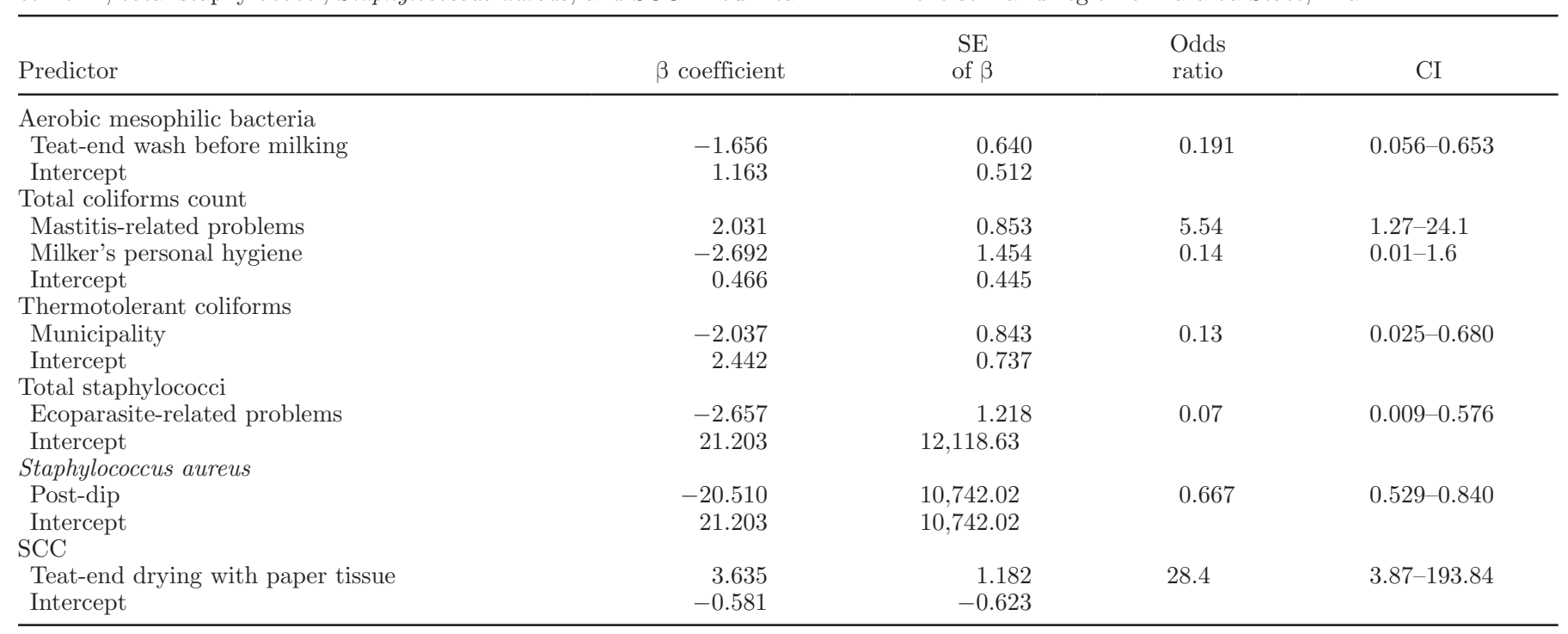

were explained only by the municipality. According to the final model, ectoparasite-related problems reported by the producers were significantly associated with lower staphylococci counts. The absence of post-dip procedure was the only risk factor linked to higher Staph. aureus contamination in raw milk. The logistic model for somatic cells included 2 significant $(P$ $<0.05)$ variables: disposable paper tissue for teat-end drying before milking and milking performed by more than one milker. The use of paper towel for teat-end drying was associated with a higher $(\mathrm{OR}=4.41)$ risk for high SCC in milk.

\section{DISCUSSION}

Although the number of farms in the region that currently meet the legislative threshold for aerobic mesophilic bacteria is high (88\%), caution is warranted in interpreting these findings because a more stringent threshold $\left(3.0 \times 10^{5} \mathrm{SCC} / \mathrm{mL}\right)$ will be defined by legislation in 2012. Considering this scenario, only 27 (54\%) farms would meet the legislative standard if no decrease occurs in total aerobic counts for raw milk in the region until 2012. Therefore, these findings strongly indicate the need to implement intervention measures to improve the microbiological quality of milk in the region. This is obviously a challenging issue because the milk value chain comprises mostly smallholder producers with considerable educational and economic limitations. Microbiological quality of bulk tank milk varies among different studies performed in Brazil. According to previous reports carried out in southern states, the frequency of farms meeting legislative standards re- garding total bacterial counts in bulk tank milk ranged from 18 to $83 \%$ (Nero et al., 2005; Arcuri et al., 2006).

Total coliform counts $>1.0 \times 10^{3} \mathrm{MPN} / \mathrm{mL}$ are considered indicative of hygiene-related problems in milk production (Murphy, 1997), although no limit exists for coliform organisms in the current Brazilian legislation for bulk tank milk. The present study showed that $29(58 \%)$ and $18(36 \%)$ bulk tank milk samples had counts exceeding $1.0 \times 10^{3} \mathrm{MPN} / \mathrm{mL}$ for total and fecal coliforms, respectively. The present findings could indicate possible hygiene problems in milking procedures in most assessed farms, because fecal coliforms such as E. coli might contaminate bulk milk through intramammary secretion or fecal contamination in the milking equipment (Van Kessel et al., 2004). Higher coliform counts also indicate possible contamination by pathogenic bacteria of public health significance.

A high positive coefficient of correlation was observed between aerobic mesophilic bacteria and total coliforms $(\mathrm{r}=0.78)$ and between aerobic mesophilic bacteria and fecal coliforms $(r=0.85)$. These findings are similar to a previous report (Arcuri et al., 2006) and therefore indicate that aerobic mesophil counts could be effectively used as the single microbiological hygienic indicator for mesophilic aerobic bacteria in raw milk.

Staphylococci organisms are major mastitis-causing agents in cattle worldwide and in Brazil (Souto et al., 2008; Whist et al., 2009). Thus, the high number of milk samples (66\%) harboring Staph. aureus could be indicative of mastitis in the investigated herds. Considering that mastitis is associated with increased somatic cells in milk (Barbano et al., 2006), a high correlation between staphylococci counts and SCC would be ex- 
pected. However, this was not observed in the present study $(\mathrm{r}=-0.11)$. Furthermore, small correlations between SCC and other bacterial counts (aerobic mesophilic bacteria and coliforms) have been observed in the present study, which corroborate a previous report (Jayarao et al., 2004).

Salmonella isolation rate $(2 \%)$ was very similar to the results previously reported in many countries. It was also similar to the frequency of $2.6 \%$ noted by Van Kessel et al. (2004) in the United States as part of the National Animal Health Monitoring System (NAHMS) Dairy Survey. However, a higher contamination rate $(11.8 \%)$ was observed in bulk milk samples in the NAHMS 2002 survey (Karns et al., 2005) when samples were analyzed by real-time PCR. Therefore, further studies on the methods used to identify Salmonella in milk and dairy products are required to evaluate the real importance of milk as a Salmonella vehicle. Moreover, such information is very important for the development of monitoring programs intended to control and reduce this pathogen in the dairy production chain.

Although SCC ranged widely in the investigated farms, high SCC, indicative of mastitis-associated problems, seemed to be a problem for certain smallholder farms only. In this sense, monitoring somatic cells in bulk tank milk in the region is needed to identify farms with mastitis-related problems and to define strategies for control measures.

The large variations observed for bacterial counts and SCC in bulk tank milk samples could suggest putative risk factors associated with bulk tank milk quality. Therefore, logistic regression models were attempted and possible risk factors associated with microbiological indicators and SCC in raw milk have been identified (Table 4). The teat-wash procedure before milking was the single factor retained in the model for aerobic mesophilic bacteria, which could explain $54 \%$ of the variation. According to this model, teat washing before milking was significantly associated with lower aerobic mesophilic contamination in raw milk $(\mathrm{OR}=0.191,95 \%$ CI: 0.056 to 0.653 ). It is known that udder cleanliness before milking is crucial to reduce microbial contamination in milk (Magnusson et al., 2006; Elmoslemany et al., 2010). In addition, poor teat-end cleanliness was significantly associated with high bacterial counts in bulk milk (Elmoslemany et al., 2009b). In view of the scientific knowledge available and the high plausibility of this variable to be considered a major factor associated with microbial contamination in milk, the present findings confirm that udder hygiene plays an important role in the quality of bulk tank milk. However, high collinearity among the predictors was observed. Among the other 11 significant predictors unconditionally as- sociated with aerobic mesophilic bacteria, teat wash was significantly correlated with 6 variables by the tetrachoric correlation test. This could explain the fact that although many unconditional associations were detected by the univariate analyses, only one factor was retained in the final model. However, the present findings suggest that premilking teat-end wash could help smallholder producers reduce aerobic mesophilic bacteria counts in raw milk. Detailed information about premilking teat cleaning and disinfection was recently published (Elmoslemany et al., 2010).

The results of the present investigation corroborated a previous report indicating a high correlation between coliform and total bacterial counts (Pantoja et al., 2009). In the present study, high coliform counts were significantly associated with herds having mastitisrelated problems reported previously by the farmer. The model explained $77.6 \%$ of the variation but the high correlation between predictors and the limitations of the cross-sectional studies in determining causality make it difficult to reach conclusions about the real role of these predictors. Again, mastitis-related problems were correlated with 7 out of 12 predictors. This association could be biologically plausible because some microorganisms in raw milk could also be mastitis-causing agents. Furthermore, a significant association between coliform and SCC has been described (Pantoja et al., 2009). In the mentioned study, coliforms increased $4.3 \%$ for every 10,000 cells $/ \mathrm{mL}$. On the other hand, no significant coefficient of correlation $(P>0.05)$ was observed in the present study between somatic cell and coliform counts when tested by tetrachoric correlation test.

According to the logistic regression model, a higher risk of milk contamination by thermotolerant coliforms was associated with milk produced in the municipality of Caturité. Dairy herds in both regions, Caturité and Boqueirão, are very similar, which makes this association very difficult to be explained. This result could be due to factors not covered in the questionnaire. Only limited information about the cleaning procedures of bulk tank was available and this could have a major effect on the microbiological findings, including coliforms.

Thermotolerant coliforms are related mainly to fecal coliforms, a potential agent of environmental mastitis. Theoretically, it makes sense to associate higher levels of thermotolerant coliforms in milk from herds with very poor hygienic procedures. However, many possible hygienic predictors identified in the univariate analysis were not retained in the final model, such as cleanliness of milking area, cleanliness of the barn, time elapsed between milking and refrigeration and milking place. The high collinearity among predictors could be related 
to this problem. Although the municipality has not been retained in the final model for somatic cells, this variable was also a predictor (Table 1) associated with somatic cells. Tetrachoric correlation between thermotolerant coliforms and somatic cells was not significant.

Curiously, a lower risk of staphylococcal contamination was observed in farms where problems associated with ectoparasites have been reported by the farmer. This might be a confounding variable because control of ectoparasites could be related to a large number of variables. On the other hand, post-dip was significantly associated with Staph. aureus reduction in raw milk in the present study. This model explained $76 \%$ of the data variability. Although premilking udder hygiene procedures are known to play a major role in the microbial quality of bulk tank milk (Elmoslemany et al., 2010), postmilking teat dip is also important for mastitis control purposes. In this sense, the findings of the present study could corroborate the benefits of post-dip in reducing Staph. aureus and consequently preventing contagious mastitis.

In regard to SCC, drying of teat-ends with disposable paper towels was the only variable retained in the final model as a risk factor associated with SCC $>400,000$ cells/mL. We strongly believe this might a confounding association because it lacks biological plausibility. In recent years, much information has been published about the importance of detailed premilking management practices and especially pre-dip followed by teat-end drying (Elmoslemany et al., 2010) in reducing somatic cells in bulk milk. The small sample size of the present study should also be considered a major problem for multivariable analysis, mainly because of the absence of variation between herds. It is crucial, however, to highlight the limitations of cross-sectional studies in determining causality in complex diseases such as mastitis. As noted earlier, the results of this study must be seen as preliminary data on milk quality indicators for semi-intensive dairy herds in semiarid northeastern Brazil. Among the models for quality indicators presented in this investigation, we identified risk factors associated with aerobic mesophilic bacteria and Staph. aureus contamination in bulk tank milk. Therefore, the present findings encourage further research, including more complex study designs and larger sample sizes, to identify risk factors associated with milk quality in semi-intensive production systems in developing areas. We strongly believe that extension activities toward implementation measures intending to improve on-farm milk quality directly depend on the precise detection of priorities for smallholders and scientific information that is still lacking in those regions.

\section{CONCLUSIONS}

This study provides baseline data for the current milk quality assessment in Paraiba State in northeastern Brazil. The current findings show high microbiological contamination in bulk tank milk. Because of upcoming stricter legislative standards, intervention measures are urgently needed on some farms to enable them to meet the standards enforced after 2012. However, it is expected that the new legislative standards will remain a challenge in the semiarid regions of northeastern Brazil, where the milk value chain comprises smallholder producers facing educational and economic limitations. Absence of premilking teat-end wash and postmilking teat dip were identified as potential risk factors for aerobic mesophilic bacteria and Staph. aureus contamination in bulk milk. Even considering the limitations of this study, the present findings suggest that milking hygiene procedures could be successfully used to improve bulk milk quality in the region. Further investigations are encouraged to use larger samples sizes and other study designs.

\section{ACKNOWLEDGMENTS}

The authors are grateful to Fundo de Desenvolvimento Científico e Tecnológico do Banco do Nordeste (Fundeci/BNB; Fortaleza-CE, Brazil) and to the National Council for Scientific and Technological Development (CNPq/proc. 483103/2007-1; Brasilia-DF, Brazil) for financial support.

\section{REFERENCES}

Andrews, W. H., and T. Hammack. 2007. Chapter 5: Salmonella. Bacteriological Analytical Manual (BAM). 8th ed. Food and Drug Administration (FDA), Washington, DC. http://www.fda.gov/ Food/ScienceResearch/LaboratoryMethods/Bacteriological AnalyticalManualBAM/UCM070149.

AOAC. 1998. Official Methods of Analysis. Vol I. 16th ed. Association of Official Analytical Chemists, Arlington VA.

APHA (American Public Health Association). 1992. Committee on Microbiological Methods for Foods: Compendium of Methods for the Microbiological Examination of Foods. American Public Health Association, Washington, DC.

Arcuri, E. F., M. A. V. P. Brito, J. R. F. Brito, S. M. Pinto, F. F. Ângelo, and G. N. Souza. 2006. Qualidade microbiológica do leite refrigerado nas fazendas. Arq. Bras. Med. Vet. Zootec. 58:440-446.

Barbano, D. M., Y. Ma, and M. V. Santos. 2006. Influence of raw milk quality on fluid milk shelf life. J. Dairy Sci. 89(E. Suppl.):E15E19.

Barkema, H. W., J. D. Van Der Ploeg, Y. H. Schukken, T. J. G. M. Lam, G. Benedictus, and A. Brand. 1999. Management style and its association with bulk milk somatic cell count and incidence rate of clinical mastitis. J. Dairy Sci. 82:1655-1663.

Brasil. 2002. Ministério da Agricultura, Pecuária e Abastecimento Instrução normativa № 51 de 18 de setembro de 2002. Regulamento Técnico de Produção, Identidade e Qualidade do Leite Tipo A, do Leite Tipo B, do Leite Tipo C, do Leite Pasteurizado e do Leite 
Cru Refrigerado e o Regulamento Técnico da Coleta de Leite Cru Refrigerado e seu Transporte a Granel. Diário Oficial da União, Brasília, DF, Brazil.

Elmoslemany, A. M., G. P. Keefe, I. R. Dohoo, and B. M. Jayarao. 2009a. Risk factors for bacteriological quality of bulk tank milk in Prince Edward Island dairy herds. Part 1: Overall risk factors. J. Dairy Sci. 92:2634-2643.

Elmoslemany, A. M., G. P. Keefe, I. R. Dohoo, and B. M. Jayarao. 2009b. Risk factors for bacteriological quality of bulk tank milk in Prince Edward Island dairy herds. Part 2: Bacteria count-specific risk factors. J. Dairy Sci. 92:2644-2652.

Elmoslemany, A. M., G. P. Keefe, I. R. Dohoo, J. J. Wichtel, H. Stryhn, and R. T. Dingwell. 2010. The association between bulk tank milk analysis for milk quality and on-farm management practices. Prev. Vet. Med. 95:32-40.

FDA. 2005. Direct Microscopic Somatic Cell Count. Center for Food Safety and Applied Nutrition. Accessed Mar. 2010. http://www. fda.gov/Food/FoodSafety/ProductSpecificInformation/MilkSafety/CodedMemoranda/MemorandaofInformation/ucm075202.htm.

IBGE (Instituto Brasileiro de Geografia e Estatística). 2008. Pesquisa da Pecuária Municipal [Municipal Agricultural Database]. Accessed Aug. 2009. http://www.sidra.ibge.gov.br/bda/pesquisas/ ppm/default.asp.

Jayarao, B. M., S. C. Donaldson, B. A. Straley, A. A. Sawant, N. V. Hegde, and J. L. Brown. 2006. A survey of foodborne pathogens in bulk tank milk and raw milk consumption among farm families in Pennsylvania. J. Dairy Sci. 89:2451-2458.

Jayarao, B. M., S. R. Pillai, A. A. Sawant, D. R. Wolfgang, and N. V. Hegde. 2004. Guidelines for monitoring bulk tank milk somatic cell and bacterial counts. J. Dairy Sci. 87:3561-3573.

Karns, J. S., J. S. Van Kessel, B. J. McCluskey, and M. L. Perdue. 2005. Prevalence of Salmonella enterica in bulk tank milk from US dairy products as determined by polymerase chain reaction. J. Dairy Sci. 88:3475-3479.

Magnusson, M., A. Christiansson, B. Svensson, and C. Kolstrup. 2006. Effect of different premilking manual teat-cleaning methods on bacterial spores in milk. J. Dairy Sci. 89:3866-3875.

Murphy, S. C. 1997. Raw milk bacteria tests: Standard plate count, preliminary incubation counts, lab pasteurized count, and coliform count. What do they mean for your farm? Pages 34-41 in Proc. Natl. Mastitis Counc. Mtg., Syracuse, NY. Natl. Mastitis Council Inc., Madison, WI.

National Mastitis Council. 1999. Laboratory Handbook on Bovine Mastitis. Natl. Mastitis Council Inc., Madison, WI.

Nero, L. A., M. R. Mattos, V. Beloti, M. A. F. Barros, P. A. N. Pinto, N. J. Andrade, W. P. Silva, and B. D. G. M. Franco. 2005. Leite cru de quatro regiões leiteiras brasileiras: Perspectivas de atendimento dos requisitos microbiológicos estabelecidos pela instrução normativa 51. Cienc. Tecn. Alim. 25:191-195.

Nero, L. A., D. Maziero, and M. S. Bezerra. 2003. Hábitos alimentares do consumidor de leite cru de Campo Mourão-PR. Arq. Bras. Med. Vet. Zootec. 57:251-260.

Pantoja, J. C. F., D. J. Reinemann, and P. L. Ruegg. 2009. Associations among milk quality indicators in raw bulk milk. J. Dairy Sci. 92:4978-4987.

Peeler, E. J., M. J. Green, J. L. Fitzpatrick, K. L. Morgan, and L. E. Green. 2000. Risk factors associated with clinical mastitis in low somatic cell count British dairy herds. J. Dairy Sci. 83:2464-2472.

Prescott, S. C. and R. S. Breed. 1910. The determination of number of body cells in milk by direct method. J. Infect. Dis. 7:632-640.

Souto, L. I., C. Y. Minagawa, E. O. Telles, M. A. Garguglio, M. Amaku, R. A. Dias, S. T. Sakata, and N. R. Benites. 2008. Relationship between occurrence of mastitis pathogens in dairy cattle herds and raw-milk indicators of hygienic-sanitary quality. J. Dairy Res. 75:121-127.

Suriyasathaporn, H. W., Y. H. Shukken, M. Nielen, and A. Brand. 2000. Low somatic cell count: A risk factor for subsequent clinical mastitis in a dairy herd. J. Dairy Sci. 83:1248-1255.

Van Kessel, J. S., J. S. Karns, L. Gorski, B. J. McCluskey, and M. L. Perdue. 2004. Prevalence of salmonellae, Listeria monocytogenes, and fecal coliforms in bulk tank milk on US dairy products. J. Dairy Sci. 87:2822-2830.

Whist, A. C., O. Osteras, and L. Solverod. 2009. Association between isolation of Staphylococcus aureus one week after calving and milk yield, somatic cell count, clinical mastitis, and culling through the remaining lactation. J. Dairy Res. 76:24-35. 